\title{
Bioconversion of Cattle Manure by Hermetia Illucens Larvae: Mineral Content Changes in Manure and Larval Biomass.
}

Joan Sanchez-Matos ( $\sim$ joan.s.matos@gmail.com )

Universidad Nacional de la Amazonía Peruana: Universidad Nacional de la Amazonia Peruana

Lara Pinto de Aráujo

Universidade Estadual de Santa Cruz

Vinnícius Henrique Cerqueira da Silva

Universidade Estadual de Santa Cruz

Ivon Pinheiro Lôbo

Universidade Estadual de Santa Cruz

Raildo Mota de Jesus

Universidade Estadual de Santa Cruz

Jose Adolfo de Almeida Neto

Universidade Estadual de Santa Cruz

\section{Research Article}

Keywords: Bioaccumulation factor, animal feed, larvae frass, biofertilizer, bioconversion, toxic elements

Posted Date: October 12th, 2021

DOl: https://doi.org/10.21203/rs.3.rs-943772/v1

License: (9) (i) This work is licensed under a Creative Commons Attribution 4.0 International License.

Read Full License 


\section{Abstract}

Bioconversion by Hermetia illucens larvae is a novel technology for organic waste treatment and valorization. However, since the possible uses of products from this process are in agriculture and livestock, the bioconversion must guarantee the mineral quality of both the Hermetia illucens larvae frass and larval biomass. Therefore, this study aimed to assess the mineral content changes for both the larval biomass and larvae frass of Hermetia illucens after the manure bioconversion to determine their suitability as animal feed and organic fertilizer, respectively. Hermetia illucens larvae were put into a plastic box containing fresh cattle manure, and the control treatment with the same conditions without larvae was established. After the first pre-pupae were detected, frass and larvae were collected, and their mineral content was analyzed. At the end of the experiment, the larvae showed increases in some micro and macronutrients, especially calcium and manganese, increasing up to 2.6 and 22.6 times the initial concentration, respectively. The toxic elements concentration was increased in larval biomass, but these levels met the international legislation for animal feed. As a result, the mineral content in larval biomass revealed that Hermetia illucens could be potentially used as animal feed, which could be comparable with fish meal, and is probably better than soybean meal. However, the larvae frass could only be used as organic fertilizer in a Canadian context, with further treatment for decreasing the chromium content being necessary.

\section{Introduction}

Animal manure is a type of organic waste generated by livestock. With the increase of intensive production systems in response to the growing worldwide demand for animal protein, high amounts of manure must be managed (Sungur et al. 2016; Feng et al. 2018). Due to manure`s nutrient and mineral content, the most common management method used for it is its direct application to soils with or without prior storage (IPCC 2006) to improve soil quality and crop yield (Fengsong et al. 2011). However, the presence of pathogens, antibiotics, veterinary drugs, and some toxic elements could limit its use on agricultural soils and carry a risk to the environment and human health (Sahito et al. 2016; Hu et al. 2017; Leclerc and Laurent 2017; Feng et al. 2018; Provolo et al. 2018; Zubair et al. 2020).

Macro and micronutrients and toxic elements are often found in a wide range of animal manures. They are linked with the animal's feed, supplementation, and manure's origin (Nicholson et al. 1999; Wang et al. 2014; Provolo et al. 2018; Qian et al. 2018; Li et al. 2019; Xu et al. 2019). Many of these are essential elements added to animal feed and play vital roles in animal health. They complement the animal's nutritional requirements and maintain proper animal growth (Dai et al. 2016; Hejna et al. 2018; Provolo et al. 2018). However, excessive supplementation and low absorption by animals of these elements can lead to high concentrations in manure (Feng et al. 2018; Guo et al. 2018; Li et al. 2019). For example, Cu, $\mathrm{Zn}, \mathrm{As}$, and $\mathrm{Cr}$ promote animal growth, disease mitigation, and feed use efficiency. Pig feed often contains higher concentrations of $\mathrm{Cu}$ and $\mathrm{Zn}$, and the animal's gut absorbs only $10-20 \%$ of these metals in feed. Thus the remaining amount of metals is excreted, which is why pig manure often shows higher 
levels of these metals than chicken and cattle manure (Nicholson et al. 1999; Fengsong et al. 2011; Ji et al. 2012; Wang et al. 2014; Ding et al. 2017; Feng et al. 2018).

The concern here is that toxic elements from manure entering the ecosystem may lead to accumulation, bioaccumulation, and biomagnification in the food chain (Zhao et al. 2014), through crop leaching and surface run-off to freshwater after their application to soils (Shi et al. 2018, 2019). Current studies reveal that land fertilizing with animal manure is the highest source of toxic elements in agricultural soils in countries with low industrial activities and the second source of toxic elements in soils, after atmospheric deposition, in industrialized countries (Shi et al. 2018, 2019). Annually, the land fertilizing with animal manure contributes, at a global level, approximately $2.9 \mathrm{kt}$ of toxic elements to the environment (Leclerc and Laurent 2017).

In addition to spreading manure on soils, the main methods of manure management used are anaerobic digestion and composting. However, toxic elements could be concentrated by these process (Hu et al. 2017; Zubair et al. 2020). Therefore, better methods of manure management must be developed which allow for the reduction and recycling of the toxic, macro and micronutrients of this waste.

A novel method for waste management that is gaining more attention due to the possibility of obtaining products of high value from this type of residue is bioconversion using fly larvae (Čičková et al. 2015; Huis 2019). Hermetia illucens is the most proposed species for the treatment and valorization of animal manure. Using this species in the process can produce larval biomass and larvae frass that could be used as alternative feed and biofertilizer, respectively (Liu et al. 2019). However, when the fly larvae are fed with manure from livestock activities, the generated larval biomass as feed is not recommended. Since 2017, the processed protein from seven edible insect species was approved by the European Union (EU) to use in aquaculture feeding. However, manure use is not allowed as an insect breeding substrate (European Commission 2017). Recently, the use of processed protein from these insects in poultry and swine feeds was authorized (European Commission 2021). Considering, that globally there are about 45.6 million tonnes per day of manure potentially available for processing (FAO; Chávez-Fuentes et al. 2017), and the potential for growing fly larvae on animal manure to recycle protein and manage organic waste from livestock production (Nordentoft et al. 2017), more research may be needed to confirm the suitability of the use of animal manure (Huis 2019).

Larval biomass can accumulate high levels of some toxic elements (up to 9 fold the cadmium concentration in the substrate) (Tschirner and Simon 2015; Purschke et al. 2017). Charlton et al. (2015) found that fly larvae fed with the swine manure of four different companies contained cadmium concentrations higher than the EU allowed limits for animal feed. Diverse studies agree with this finding and have highlighted the ability of Hermetia illucens to accumulate cadmium from spiked substrates (Diener et al. 2015a; Fels-Klerx et al. 2016; Gao et al. 2017; Purschke et al. 2017; Bulak et al. 2018) and substrates without cadmium, too (Tschirner and Simon 2015; Biancarosa et al. 2017; Schmitt et al. 2019). Despite this concern, Hermetia illucens can also accumulate essential minerals for animal nutrition, such as Cu, Zn, and Ca (Diener et al. 2015b; Tschirner and Simon 2015; Bulak et al. 2018). Given this, various 
studies reveal that larvae meal from Hermetia illucens as feed for fish, pig, and poultry is a promising substitute for fish and soy meal (Stadtlander et al. 2017; Xiao et al. 2018; Biasato et al. 2019; Yu et al. 2019).

Similarly, after co-products bioconversion, larvae frass have shown to be an interesting alternative for chemical fertilizer, increasing the development of crops such as tomato and leaf lettuce (Setti et al. 2019). However, when the substrates are contaminated with toxic elements, some elements can become concentrated, and others reduced. For example, Hermetia illucens larvae can concentrate $\mathrm{Pb}$ in spiked substrates (Diener et al. 2015b; Fels-Klerx et al. 2016). In contrast, Cai et al. (2018) detected decreasing concentrations of $\mathrm{Cd}, \mathrm{Cr}, \mathrm{Cu}, \mathrm{Hg}, \mathrm{Zn}$, and $\mathrm{Pb}$ from municipal sludge sewage. Miranda et al. (2021) demonstrated that Hermetia illucens could reduce animal manure's mineral content depending on the system scale. Accordingly, Hermetia illucens larvae could be a potential agent for treating toxic elements in contaminated wastes.

Thus, in the context of the need for manure treatment and valorization, besides the potential of Hermetia illucens for feed and biofertilizer production from decayed materials, the aims of this study were: 1) to assess the suitability of Hermetia illucens larvae and frass from animal manure bioconversion as animal feed and biofertilizer by taking into consideration its mineral content and 2) to analyze changes in mineral concentrations, from larvae to pre-pupae, on larvae biomass and cattle manure after the bioconversion.

\section{Materials And Methods}

\subsection{Materials}

\section{Hermetia illucens larvae and cattle manure collecting}

Larvae of Hermetia illucens were obtained from eggs of wild flies found on the composting project of the State University of Santa Cruz (Ilhéus-Bahia-Brazil). The cattle manure was collected from an experimental farm from the university mentioned above. The Hermetia illucens larvae rearing process during the first six days and cattle manure collecting are described in the recently published paper of Sanchez Matos and colleagues (2021). Table 1 shows the mineral content of chicken feed and cattle manure used for the rearing of Hermetia illucens larvae and the experiments, respectively.

Table 1. Mineral content of chicken feed and cattle manure used in experiments for the growth of young larvae (mean $\pm 95 \%$ confidence interval) 


\begin{tabular}{|lll|}
\hline Elements & Chicken feed & Cattle manure \\
\hline Micronutrients & & \\
\hline $\mathrm{Cu}\left(\mathrm{g} \mathrm{kg}^{-1}\right)$ & $0.02 \pm 0.09$ & $0.04 \pm 0.08$ \\
\hline $\mathrm{Fe}\left(\mathrm{g} \mathrm{kg}^{-1}\right)$ & $1.87 \pm 0.41$ & $1.81 \pm 0.81$ \\
\hline $\mathrm{Mn}\left(\mathrm{g} \mathrm{kg}^{-1}\right)$ & $0.04 \pm 0.01$ & $0.53 \pm 0.04$ \\
\hline $\mathrm{Zn}\left(\mathrm{g} \mathrm{kg}^{-1}\right)$ & $0.32 \pm 0.11$ & $0.32 \pm 0.74$ \\
\hline $\mathrm{Macronutrients}$ & & \\
\hline $\mathrm{Ca}\left(\mathrm{g} \mathrm{kg}^{-1}\right)$ & $18.72 \pm 8.76$ & $6.06 \pm 5.54$ \\
\hline $\mathrm{K}\left(\mathrm{g} \mathrm{kg}^{-1}\right)$ & $11.45 \pm 0.61$ & $2.06 \pm 1.39$ \\
\hline $\mathrm{Mg}\left(\mathrm{g} \mathrm{kg}^{-1}\right)$ & $2.63 \pm 0.10$ & $2.98 \pm 1.06$ \\
\hline $\mathrm{Na}\left(\mathrm{g} \mathrm{kg}^{-1}\right)$ & $3.98 \pm 0.30$ & $1.25 \pm 1.39$ \\
\hline $\mathrm{P}\left(\mathrm{g} \mathrm{kg}^{-1}\right)$ & $10.79 \pm 2.97$ & $3.06 \pm 2.35$ \\
\hline $\mathrm{S}\left(\mathrm{g} \mathrm{kg}^{-1}\right)$ & $2.36 \pm 0.11$ & $1.89 \pm 0.29$ \\
\hline $\mathrm{Toxic} \mathrm{elements}$ & & \\
\hline $\mathrm{Cd}\left(\mathrm{mg} \mathrm{kg}^{-1}\right)$ & $<0.001$ & $0.29 \pm 0.48$ \\
\hline $\mathrm{Cr}\left(\mathrm{mg} \mathrm{kg}^{-1}\right)$ & $2.91 \pm 2.61$ & $3.05 \pm 1.78$ \\
\hline $\mathrm{Pb}\left(\mathrm{mg} \mathrm{kg}^{-1}\right)$ & $<0.001$ & $<0.001$ \\
\hline
\end{tabular}

\subsection{Experimental setup}

The cattle manure was homogenized, and one $\mathrm{kg}$ of this manure was introduced into a plastic box with four replicates. Subsequently, 10006 day-old larvae were spread over manure. For each box containing manure and larvae, a control with the same characteristics without larvae was established. The experiments were carried out until the first prepupae appeared. The experimental conditions and more details of the experimental setup can be found in the previous study of Sanchez Matos et al. (2021).

\subsection{Analytical methods}

\section{Mineralization and elemental analysis}


The larvae and manure were dried at $60^{\circ} \mathrm{C}$ for 48 hours and ground in a ceramic mortar. Dry samples of $0.3 \mathrm{~g}$ of manure and larvae were weighed and digested with $4 \mathrm{~mL} \mathrm{HNO}, 0.5 \mathrm{~mL} \mathrm{HCl}$ and $2.5 \mathrm{~mL} \mathrm{H} 2 \mathrm{O} 2$ into perfluoroalkoxy (PFA) vessels using a multimode microwave apparatus (CEM Mars Xpress). The samples were digested according to the following program: ramp in $2 \mathrm{~min}$ to $120^{\circ} \mathrm{C}, 8 \mathrm{~min}$ at $120^{\circ} \mathrm{C}, 5$ min from $120^{\circ} \mathrm{C}$ to $180^{\circ} \mathrm{C}$, and $15 \mathrm{~min}$ at $180^{\circ} \mathrm{C}$. After digestion, the contents in the PFA vessels were transferred to $50 \mathrm{~mL}$ conical centrifuge tubes, then filled to $15 \mathrm{~mL}$ with deionized water. For digested samples of larvae, aliquots of these were diluted 20 -fold with ultrapure water. These solutions were analyzed by an inductively coupled plasma optical emission spectrometry (ICP OES), model 710-ES Varian (Mulgrave, Australia), with axial configuration. This instrument was equipped with a MEINHARD ${ }^{8}$ concentric nebulizer (Santa Clara, USA), coupled to a cyclonic nebulization chamber - single pass Varian (Mulgrave, Australia), Varian quartz torch (Mulgrave, Australia), and solid-state detector with an arrangement of CCD diodes. Argon 99.998\% White Martins / Praxair (Bahia, Brazil) was used to generate the plasma and the nebulization system. Specsol ${ }^{\circledR}$ primary monoelemental standards of $1000 \mathrm{mg} \mathrm{L}^{-1}$ for $\mathrm{Fe}, \mathrm{Cu}, \mathrm{Mn}, \mathrm{Cd}, \mathrm{Cr}, \mathrm{Pb}$ and, $\mathrm{Zn} ; 10000 \mathrm{mg} \mathrm{L}^{-1}$ for $\mathrm{Ca}, \mathrm{Mg}, \mathrm{K}, \mathrm{P}, \mathrm{S}$ and, $\mathrm{Na}$ in $5 \% \mathrm{v} \mathrm{v}^{-1}$ were employed for secondary standards dilutions used on calibration curve generating. The spectral lines were, in turn, as follows: (nm) for Cu, 327.395; Fe, 238.204; Mn, 257.610; Zn, 213.857; Ca, 373.690; K, 766.491; P, 213.618; $\mathrm{S}, 181.972 ; \mathrm{Mg} 279.800 ; \mathrm{Cd}, 214.439 ; \mathrm{Cr}, 267.716 ; \mathrm{Pb}, 220.353$ and $\mathrm{Na}$ 589.592. All glassware was decontaminated in $10 \%\left(\mathrm{v} \mathrm{v}^{-1}\right)$ nitric acid for $24 \mathrm{~h}$ and rinsed with ultrapure water.

The Bioaccumulation factor (BAF) was calculated on a dried matter basis (Walker 1990; Diener et al. 2015b):

\section{$B A F=\frac{\text { Concentration in organism }\left(C_{i}\right)}{\text { Concentration in feed }\left(C_{0}\right)}$}

Therefore, a BAF greater than 1 implies bioaccumulation of the element from the substrate into the larvae (Fels-Klerx et al. 2016).

\subsection{Data analysis}

The data were analyzed using R Studio statistical software (version 3.4.2 R-Studio 2017). The homogeneity of variance and normality of distribution were tested using Levene's test and Shapiro Wilk's test. The statistical significance was determined by Student's t-test $(p<0.05)$. The statistical significance was assessed only for $\mathrm{Ca}, \mathrm{Mg}, \mathrm{Mn}, \mathrm{Cd}, \mathrm{Cr}$, and $\mathrm{Pb}$ content in larvae, using a non-parametric Wilcoxon test $(\mathrm{p}<0.05)$. These statistical tests to assess the significant difference were applied to $\mathrm{CM}+\mathrm{HI}$ (treatment with Hermetia illucens larvae) vs. CM (control treatment) and prepupae (first prepupae) vs. young larvae.

\section{Results And Discussion}




\subsection{Mineral content changes in Hermetia illucens larvae frass after manure bioconversion}

The bioconversion of organic materials was able to cause changes in the mineral content of the substrates. In this study, as shown in Table 2, $\mathrm{Cu}, \mathrm{Mn}$, and $\mathrm{Na}$ content were significantly increased, and $\mathrm{Ca}$ and $\mathrm{K}$ content showed a significant reduction in Hermetia illucens frass after cattle manure bioconversion. However, Fe, Mg, P, S, Zn, and the content of the toxic metals showed no marked changes. This finding is similar to the effect of Musca domestica larvae only in $\mathrm{Cu}, \mathrm{Fe}, \mathrm{Na}, \mathrm{P}$, and $\mathrm{S}$ content of cattle manure reported by Hussein et al. (2017). These differences could be linked to two factors: 1) the difference between the bioaccumulation factors of Musca domestica and Hermetia illucens, and 2) the higher water and dry matter reduction by Musca domestica in the cited study $(37 \%)$ than for Hermetia illucens in this study (16.8\%). Considering the potential use of larvae frass as biofertilizers, great attention should be given to high rates of reduction of organic matter of waste and low levels of element uptake, which could lead to an accumulation of undesired elements. For example, Zhu et al. (2015) reported a slight increase of $11 \%$ and $9 \%$ of initial $\mathrm{Cd}$ and $\mathrm{Cr}$ concentrations, respectively, and a 2.5 fold increase in the $\mathrm{Pb}$ concentration after pig manure bioconversion by Musca domestica larvae. The authors also registered a reduction of $74 \%$ in water content. On the other hand, Proc et al.(2020a) found a significant increase in the $\mathrm{Cd}$ content and a considerable reduction in dry matter $(64.7 \%)$ of fish feed not spiked by the action of Hermetia illucens larvae. Furthermore, in substrates spiked with cadmium and lead solutions, the concentrations of these elements increased by up to 10\%; a 3.7 fold increase on the initial $\mathrm{Cd}$ and $\mathrm{Pb}$ concentration, respectively, after bioconversion by Hermetia illucens larvae (Fels-Klerx et al. 2016). This effect could be detrimental if the concentrations of the toxic metals in the substrate are very close to the limit values for a particular use. The Hermetia illucens larvae could increase the concentration of these elements, thereby causing these to exceed allowed values. Furthermore, monitoring of toxic elements levels in substrates used as feed for Hermetia illucens larvae is recommended. 
Table 2

Mineral content in Hermetia illucens larvae and resídues after cattle manure bioconversion (mean \pm 95\% confidence interval)

\begin{tabular}{|c|c|c|c|c|c|c|c|c|}
\hline Elements & $\begin{array}{l}\text { Young } \\
\text { larvae }\end{array}$ & Larvae & $p$-value* & $\begin{array}{l}\text { CM } \\
\text { (Residue) }\end{array}$ & $\begin{array}{l}\mathrm{CM}+\mathrm{HI} \\
\text { (frass) }\end{array}$ & $p$-value* & $\begin{array}{l}\text { Fish } \\
\text { meal** }\end{array}$ & 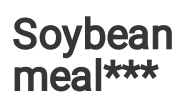 \\
\hline \multicolumn{9}{|c|}{ Micro and macronutrients } \\
\hline $\begin{array}{l}\mathrm{Ca}(\mathrm{g} \\
\left.\mathrm{kg}^{-1}\right)\end{array}$ & $\begin{array}{l}24.62 \\
\pm 1.93\end{array}$ & $\begin{array}{l}66.35 \\
\pm 1.62\end{array}$ & 0.00 & $\begin{array}{l}7.98 \pm \\
1.74\end{array}$ & $\begin{array}{l}4.95 \pm \\
0.34\end{array}$ & 0.01 & 30.3 & 3 \\
\hline $\begin{array}{l}\mathrm{Cu}(\mathrm{g} \\
\left.\mathrm{kg}^{-1}\right)\end{array}$ & $<0.006$ & $\begin{array}{l}0.02 \pm \\
0\end{array}$ & - & $\begin{array}{l}0.04 \pm \\
0.01\end{array}$ & $\begin{array}{l}0.05 \pm \\
0.01\end{array}$ & 0.04 & 0.03 & 0.01 \\
\hline $\begin{array}{l}\mathrm{Fe}\left(\mathrm{g} \mathrm{kg}^{-}\right. \\
\left.{ }^{1}\right)\end{array}$ & $\begin{array}{l}0.75 \pm \\
0.03\end{array}$ & $\begin{array}{l}1.06 \pm \\
0.12\end{array}$ & 0.00 & $\begin{array}{l}2.06 \pm \\
0.98\end{array}$ & $\begin{array}{l}2.00 \pm \\
0.38\end{array}$ & 0.83 & 0.91 & 0.15 \\
\hline $\begin{array}{l}\mathrm{K}\left(\mathrm{g} \mathrm{kg}^{-}\right. \\
1)\end{array}$ & $\begin{array}{l}17.84 \\
\pm 1.11\end{array}$ & $\begin{array}{l}18.69 \\
\pm 0.6\end{array}$ & 0.06 & $\begin{array}{l}4.78 \pm \\
0.65\end{array}$ & $\begin{array}{l}8.05 \pm \\
1.89\end{array}$ & 0.01 & 8.5 & 21.5 \\
\hline $\begin{array}{l}\mathrm{Mg}(\mathrm{g} \\
\left.\mathrm{kg}^{-1}\right)\end{array}$ & $\begin{array}{l}4.57 \pm \\
0.29\end{array}$ & $\begin{array}{l}6.65 \pm \\
0.23\end{array}$ & 0.00 & $\begin{array}{l}4.83 \pm \\
0.82\end{array}$ & $\begin{array}{l}5.14 \pm \\
0.83\end{array}$ & 0.31 & 3 & 3.1 \\
\hline $\begin{array}{l}\mathrm{Mn}(\mathrm{g} \\
\left.\mathrm{kg}^{-1}\right)\end{array}$ & $\begin{array}{l}0.10 \pm \\
0.01\end{array}$ & $\begin{array}{l}2.26 \pm \\
0.05\end{array}$ & 0.00 & $\begin{array}{l}0.69 \pm \\
0.16\end{array}$ & $\begin{array}{l}0.34 \pm \\
0.06\end{array}$ & 0.01 & 0.01 & 0.03 \\
\hline $\begin{array}{l}\mathrm{Na}(\mathrm{g} \\
\left.\mathrm{kg}^{-1}\right)\end{array}$ & $\begin{array}{l}2.53 \pm \\
0.11\end{array}$ & $\begin{array}{l}2.63 \pm \\
0.13\end{array}$ & 0.08 & $\begin{array}{l}1.88 \pm \\
0.03\end{array}$ & $\begin{array}{l}2.3 \pm \\
0.16\end{array}$ & 0.01 & 11.1 & 0.01 \\
\hline $\begin{array}{l}\mathrm{P}\left(\mathrm{g} \mathrm{kg}^{-}\right. \\
\left.{ }^{-}\right)\end{array}$ & $\begin{array}{l}12.68 \\
\pm 1.03\end{array}$ & $\begin{array}{l}12.15 \\
\pm 0.39\end{array}$ & 0.15 & $\begin{array}{l}3.31 \pm \\
1.44\end{array}$ & $\begin{array}{l}3.67 \pm \\
0.61\end{array}$ & 0.40 & 21.6 & 6.2 \\
\hline $\begin{array}{l}\mathrm{S}\left(\mathrm{g} \mathrm{kg}^{-}\right. \\
1)\end{array}$ & $\begin{array}{l}4.35 \pm \\
0.44\end{array}$ & $\begin{array}{l}4.88 \pm \\
0.15\end{array}$ & 0.02 & $\begin{array}{l}2.58 \pm \\
0.61\end{array}$ & $\begin{array}{l}2.78 \pm \\
0.23\end{array}$ & 0.29 & $4.00^{\mathrm{a}}$ & 4.2 \\
\hline $\begin{array}{l}\mathrm{Zn}(\mathrm{g} \\
\left.\mathrm{kg}^{-1}\right)\end{array}$ & $\begin{array}{l}0.43 \pm \\
0.03\end{array}$ & $\begin{array}{l}0.54 \pm \\
0.05\end{array}$ & 0.00 & $\begin{array}{l}0.41 \pm \\
0.15\end{array}$ & $\begin{array}{l}0.50 \pm \\
0.17\end{array}$ & 0.17 & 0.05 & 0.05 \\
\hline \multicolumn{9}{|c|}{ Toxic elements } \\
\hline $\begin{array}{l}\mathrm{Cd}(\mathrm{mg} \\
\left.\mathrm{kg}^{-1}\right)\end{array}$ & $\begin{array}{l}0.02 \pm \\
0.04\end{array}$ & $\begin{array}{l}0.34 \pm \\
0.03\end{array}$ & 0.00 & $\begin{array}{l}0.45 \pm \\
0.04\end{array}$ & $\begin{array}{l}0.42 \pm \\
0.05\end{array}$ & 0.08 & - & - \\
\hline $\begin{array}{l}\mathrm{Cr}(\mathrm{mg} \\
\left.\mathrm{kg}^{-1}\right)\end{array}$ & $\begin{array}{l}1.09 \pm \\
0.13\end{array}$ & $\begin{array}{l}2.46 \pm \\
0.11\end{array}$ & 0.00 & $\begin{array}{l}2.89 \pm \\
2.03\end{array}$ & $\begin{array}{l}5.76 \pm \\
5.51\end{array}$ & 0.14 & - & - \\
\hline $\begin{array}{l}\mathrm{Pb}(\mathrm{mg} \\
\left.\mathrm{kg}^{-1}\right)\end{array}$ & $<0.002$ & $\begin{array}{l}0.19 \pm \\
0.36\end{array}$ & - & $<0.002$ & $<0.002$ & - & - & - \\
\hline
\end{tabular}


The mineral content of Hermetia illucens larvae frass obtained in this study was compared with European, Canadian, American, and Brazilian maximum limits of contaminants in organic fertilizers to assess its suitability for agricultural use. As shown in Tables 2 and $3, \mathrm{Cu}, \mathrm{Zn}, \mathrm{Cd}$, and Pb content met the maximum limits established by cited legislations; however, $\mathrm{Cr}$ content only met the Canadian maximum limits. A reason for this finding could be linked to $\mathrm{Cr}$ supplementation in cattle feeds and subsequent transfer to excreta. Usually, diverse forms of $\mathrm{Cr}$ are used in feed to treat mental, physical, or metabolic stress in cattle They sometimes can exceed the maximum limits for animal feed by six fold, as reported by Li et al.(2019). Therefore, in this case, it would be recommendable that a subsequent treatment process can be used to improve the suitability of larvae frass, for example, for co-composting with other residual materials that have low $\mathrm{Cr}$ content. 
Table 3

Maximum limits of mineral content in animal feed and organic fertilizer

\begin{tabular}{|c|c|c|c|c|c|c|c|}
\hline \multirow[t]{2}{*}{ Elements } & \multicolumn{3}{|c|}{ Maximum Limits for feed } & \multicolumn{4}{|c|}{ Maximum Limits for organic fertilizer } \\
\hline & $\mathrm{EU}^{1}$ & USA $^{2}$ & Canada ${ }^{3}$ & $\mathrm{EU}^{4}$ & USA $^{5}$ & Canada $^{6}$ & Brazil 7 \\
\hline $\mathrm{Ca}\left(\mathrm{g} \mathrm{kg}^{-1}\right)$ & - & - & - & - & - & - & - \\
\hline $\mathrm{Cu}\left(\mathrm{g} \mathrm{kg}^{-1}\right)$ & - & $0.25^{p, s} ; 0.1^{f}$ & - & 0.3 & 1.5 & 0.4 & - \\
\hline $\mathrm{Fe}\left(\mathrm{g} \mathrm{kg}^{-1}\right)$ & - & $0.5^{\mathrm{p}} ; 3.0^{\mathrm{s}}$ & - & - & - & - & - \\
\hline $\mathrm{K}\left(\mathrm{g} \mathrm{kg}^{-1}\right)$ & - & $10.0^{\mathrm{a}}$ & - & - & - & - & - \\
\hline $\mathrm{Mg}\left(\mathrm{g} \mathrm{kg}^{-1}\right)$ & - & $5.0^{\mathrm{p}} ; 2.4^{\mathrm{s}} ; 3^{\mathrm{f}}$ & - & - & - & - & - \\
\hline $\mathrm{Mn}\left(\mathrm{g} \mathrm{kg}^{-1}\right)$ & - & $2.0^{\mathrm{p}} ; 1.0^{\mathrm{s}}$ & - & - & - & - & - \\
\hline $\mathrm{Na}\left(\mathrm{g} \mathrm{kg}^{-1}\right)$ & - & - & - & - & - & - & - \\
\hline$P\left(g_{k g}^{-1}\right)$ & - & $10.0^{a}$ & - & - & - & - & - \\
\hline $\mathrm{S}\left(\mathrm{g} \mathrm{kg}^{-1}\right)$ & - & $4.0^{\mathrm{a}}$ & - & - & - & - & - \\
\hline $\mathrm{Zn}\left(\mathrm{g} \mathrm{kg}^{-1}\right)$ & - & $0.5^{\mathrm{p}} ; 1^{\mathrm{s}} ; 0.25^{\mathrm{f}}$ & - & 0.8 & 2.8 & 0.7 & \\
\hline $\mathrm{Cd}\left(\mathrm{mg} \mathrm{kg}^{-1}\right)$ & 2.0 & $10^{\mathrm{a}}$ & 0.4 & 1.5 & 39 & 3 & 3.0 \\
\hline $\mathrm{Cr}\left(\mathrm{mg} \mathrm{kg}^{-1}\right)$ & - & $100^{s} ; 500^{p}$ & - & 2.0 & - & 210 & 2.0 \\
\hline $\mathrm{Pb}\left(\mathrm{mg} \mathrm{kg}^{-1}\right)$ & 10.0 & $10.0^{a}$ & 8.0 & 120.0 & 300 & 150 & 150.0 \\
\hline \multicolumn{8}{|c|}{$\begin{array}{l}{ }^{1} \text { Source: Directive 2002/32/EC of the European Parliament and of the Council of } 7 \text { May } 2002 \text { on } \\
\text { undesirable substances in animal feed. }{ }^{2} \text { Source: National Research Council (2005). Mineral tolerance } \\
\text { of animals. }{ }^{3} \text { Source: Canadian Food Inspection Agency (2015). RG-8 Regulatory Guidance: } \\
\text { Contaminants in Feed. }{ }^{4} \text { Source: Regulation (EU) } 2019 / 1009 \text { of the European Parliament and of the } \\
\text { Council of } 5 \text { June } 2019 \text { laying down rules on the making available on the market of EU fertilising } \\
\text { products. }{ }^{5} \text { Source: Code of Federal Regulations Part 503-Standards for the Use or Disposal of Sewage } \\
\text { Sludge. } .^{6} \text { Source: Canadian Council of the Ministers of the Environment (2005). Guidelines for } \\
\text { compost quality. }{ }^{7} \text { Source: Instrução Normativa SDA N }{ }^{\circ} 27 \text { do } 05 \text { de Junho de } 2006 \text {, Anexo V: Limites } \\
\text { máximos de contaminantes admitidos em fertilizantes orgânicos e condicionadores de solo. a. } \\
\text { concentration value for poultry, swine and fish feed. f: concentration value for fish feed. }{ }^{p} \text { : } \\
\text { concentration value for poultry feed. s: concentration value for swine feed. }\end{array}$} \\
\hline
\end{tabular}

\subsection{Mineral content changes in Hermetia illucens larval biomass}


Fly larvae can degrade different types of substrates, assimilating the minerals therein for growth and development. Table 2 shows the mineral concentration of initial larvae (young larvae) and larvae (first prepupae appeared) of Hermetia illucens. Some macronutrients $(\mathrm{K}, \mathrm{Na}$, and $\mathrm{P})$ did not have marked changes at the end of the bioconversion process. On the other hand, other micro and macronutrients, such as $\mathrm{Ca}, \mathrm{Cu}, \mathrm{Fe}, \mathrm{Mg}, \mathrm{Mn}, \mathrm{S}$, and Zn, presented significant increases. Proc et al.(2020b) also found increases in $\mathrm{Ca}, \mathrm{Cu}, \mathrm{Fe}, \mathrm{Mg}$, and $\mathrm{Mn}$ concentrations; however, $\mathrm{K}, \mathrm{Na}, \mathrm{P}, \mathrm{S}$, and $\mathrm{Zn}$ content decreased in larvae at the end of fish feed bioconversion. The reason for the differences between these studies could be linked to the nutritional composition of substrates. In this regard, Tschirner and Simon (2015) revealed that mineral content changes in biomass of Hermetia illucens larvae depend on the type of substrate. For example, the authors found that $\mathrm{K}, \mathrm{Na}, \mathrm{P}$, and $\mathrm{Mg}$ content decreased in larvae fed with a mixture of middlings from a feed mill. When larvae were fed with dried distillers' grains with solubles made from barley, corn, wheat, and sugar syrups (protein group), the $\mathrm{Cu}, \mathrm{Fe}, \mathrm{K}, \mathrm{Mg}, \mathrm{Mn}, \mathrm{Na}, \mathrm{P}$, and $\mathrm{Zn}$ content decreased. However, in larvae fed with dried sugar beet pulp, only $\mathrm{Cu}, \mathrm{Fe}, \mathrm{P}$ and $\mathrm{Cu}$ decreased, and the remaining elements increased.

Among all the evaluated elements, calcium was the most increased in larval biomass at the end of the experiment, with a 2.6 fold increase in the initial concentration. This result is consistent with the increase in the calcium content in Hermetia illucens larvae fed with fish feed, up to 2.3 times the initial concentration of young larvae, reported by Proc et al.(2020b), and it is also similar to the results obtained in larvae fed with co-products (dried sugar beet pulp), up to 2.7 times the initial calcium concentration, highlighted by Tschirner and Simon (2015). Previous studies with other fly larvae (Musca autumnalis) have revealed that large amounts of $\mathrm{Ca}$ are ingested and stored in the Malpighian tubules during the larval stage, to subsequently be used during the pupariation process (Darlington et al. 1983; Grodowitz and Broce 1983). This calcium uptake by fly larvae depends on the concentration of this element in the diet (Dube et al. 2000).

Regarding the toxic elements, the $\mathrm{Cd}, \mathrm{Cr}$, and $\mathrm{Pb}$ concentrations in larvae were significantly increased (Table 2). The Cd content increase could be linked with the high Ca content in Hermetia illucens larvae, inherent to insects. Cd uptake is through $\mathrm{Ca}^{2+}$ channels in the intestinal cells (Braeckman et al. 1999; Craig and Hare 1999; Buchwalter and Luoma 2005) and this element is mainly accumulated in the larvae body (47\%-93\%) and less amount is excreted in the feces (Wu et al. 2020). However, the Pb content increase would be linked with the Pb content in the substrate as related by Tschirner and Simon (2015) and Diener et al.(2015b), both for spiked and not spiked substrates with Pb solutions, respectively.

On the other hand, a comparison of the mineral content in larval biomass was carried out in other studies to identify if the concentrations of minerals depend on the type of substrate (not spiked with mineral solutions) when it is feed co-product or waste. Table S1 (in supplementary material) shows a wide variation in the mineral content of larval biomass with apparently no pattern according to the type of substrate used for rearing. For instance, calcium content obtained in larvae was higher than the values obtained in larvae fed with feeds and co-products, and only similar with larvae reared in dried sugar beet pulp. However, this does not mean that all larvae reared in residues will have more calcium than those 
obtained from co-products or animal feed. For example, in the case of larvae fed with restaurant waste (Spranghers et al. 2017), kitchen waste and chicken manure (Shumo et al. 2019) had lower amounts of calcium than those from the other substrates. In this study, the Cu content in larvae was higher than that fed with feeds and in line with larvae fed with chicken manure and kitchen waste (Shumo et al. 2019) but lower than the $\mathrm{Cu}$ content in commercial larvae (Irungu et al. 2018). Furthermore, regarding $\mathrm{K}, \mathrm{Mg}$, and $\mathrm{P}$ content, these were similar to the content of larvae fed with chicken feed (Dierenfeld and King 2008) and $\mathrm{Na}$ content was in line with the content in larvae grown in poultry and pig manure (Newton et al. 2005). $\mathrm{Zn}$ and Fe content in the present study were higher in larvae fed with feeds or co-products and only lower than larvae reared in chicken manure (Shumo et al. 2019), and the Mn content was higher than all the Mn concentrations in larvae from the cited studies.

Regarding the content of the toxic element, the Cd concentration in larvae fed with cattle manure of this study was lower than all the Cd content in larvae fed with other types of waste and co-products, and only in line with larvae fed with chicken feed (Fels-Klerx et al. 2016). However, $\mathrm{Cr}$ content was only lower than the content of this metal in larvae fed with municipal sewage sludge and $\mathrm{Pb}$ concentrations were higher than for all the $\mathrm{Pb}$ contents in larvae grown in feeds, some co-products, and especially municipal sewage sludge.

The high variations among the mineral contents in larvae fed both feeds, co-products or waste, could be linked to different factors, such as different experimental setups (Bosch et al. 2019a, b), different harvest times (Liu et al. 2017), different fly strains (Zhou et al. 2013) and the different nutritional contents of substrates (Tschirner and Simon 2015).

The micro and macronutrients in larvae were compared with the mineral content of fish and soybean meals, as shown in Table 2. The larvae's $\mathrm{Ca}, \mathrm{Fe}, \mathrm{Mg}, \mathrm{Mn}$, and $\mathrm{S}$ contents were higher than in fish and soybean meal. The $\mathrm{Cu}, \mathrm{Na}$, and $\mathrm{P}$ contents were higher in the fish meal than in the others; however, they were higher in larvae than in the soybean meal. The $\mathrm{K}$ content in larvae was lower than in soybean meal but higher than in fish meal. The $\mathrm{Zn}$ concentration was similar to that in larvae, fish meal, and soybean meal. Therefore, the mineral content of Hermetia illucens larvae is comparable with fish meal and possibly better than soybean meal.

The mineral content in larvae was also compared with the maximum limits for feeds established by different countries. As shown in Tables 2 and 3, the toxic elements in larvae met the EU, USA (United States of America), and Canada concentration limits for $\mathrm{Cd}, \mathrm{Cr}$, and $\mathrm{Pb}$. For micro and macronutrients, EU and Canadian legislation has not established maximum limits; therefore, the values of these elements in larvae were compared with the limits established by the USA. The Cu level in larval biomass met the maximum limit for pig, poultry, and fish feed. Furthermore, Fe and $\mathrm{Zn}$ content only met the maximum limit for pig feed. However, K, Mg, Mn, P, and S concentrations were slightly higher than the maximum limits for poultry, pig, and fish feed. These results are promising for two reasons: 1) the safe levels of toxic elements and 2) despite the slightly higher mineral levels compared with maximum levels for feed, the 
larval biomass could be used partially in feeds by adjusting the mineral content according to the animal's nutritional requirements.

\subsection{Bioaccumulation of toxic elements, micro and macronutrients in Hermetia illucens larvae}

The bioaccumulation factors (BAF) of micro and macronutrients and toxic elements in larval biomass increased from young to adult larvae (Fig. 1). The BAF of elements in larvae that were higher than 1 showed the following trend in this study: $\mathrm{Ca}>\mathrm{K}>\mathrm{Mn}>\mathrm{P}>\mathrm{S}>\mathrm{Mg}>\mathrm{Na}>\mathrm{Zn}>\mathrm{Cd}$.

These results were compared with the BAF of different elements in Hermetia illucens larvae fed with artificially uncontaminated substrates of previous studies (Tschirner and Simon 2015; Biancarosa et al. 2017; Schmitt et al. 2019; Proc et al. 2020a). As was previously observed in the larvae concentrations, there is a wide variation range in the BAF of elements of different studies; however, the BAFs of Ca, Mg, $\mathrm{Mn}$, and $\mathrm{Cd}$ in all studies were $>1$, thereby revealing bioaccumulation. $\mathrm{Ca}, \mathrm{Mg}$, and $\mathrm{Mn}$ are essential elements for insects' metabolic processing and development (Clark 1958; Ben-Shahar 2018); however, Cd is considered a toxic element and, as mentioned, is linked with the calcium content in fly larvae. For instance, in Musca domestica larvae that generally contain tenfold less calcium than Hermetia illucens larvae (Gold et al. 2018), the BAF of cadmium is < 1(Wang et al. 2017; Negi et al. 2020), on the other hand, in Hermetia illucens larvae, this factor often exceeds the value of 1 . This $\mathrm{Cd}$ and Ca relationship is also in line with the BAF obtained when Hermetia illucens larvae were fed with substrates spiked with cadmium solutions at different concentrations (Diener et al. 2015b; Fels-Klerx et al. 2016; Purschke et al. 2017; Bulak et al. 2018; Wang et al. 2021). Consequently, great care should be taken regarding the cadmium content in substrates used as feed for Hermetia illucens larvae since this can accumulate up to almost tenfold the cadmium concentration of substrate in larval biomass (Tschirner and Simon 2015).

\section{Conclusion}

In this study, the cattle manure bioconversion by Hermetia illucens larvae was studied by obtaining larval biomass and frass. The $\mathrm{Ca}, \mathrm{Cu}, \mathrm{Fe}, \mathrm{Mg}, \mathrm{Mn}, \mathrm{S}$, and $\mathrm{Zn}$ content in larvae increased through bioconversion. The biomass larval showed promise for partial use as animal feed in countries where waste-fed insects would be allowed due to the high micro and macronutrients content and safe toxic metal levels. However, more studies are needed to assess the microbiological and chemical (antibiotics, veterinary medicines, and allergens) hazards of using animal manure as growing media for Hermetia illucens larvae.

Furthermore, considering the mineral content, Hermetia illucens larvae frass was only suitable as organic fertilizer in a Canadian context due to its $\mathrm{Cr}$ concentration. So further treatment, such as co-composting with low chromium residual materials, would be necessary and more controls in chromium supplementation for livestock to improve the suitability of larvae frass obtained from the bioconversion of manure.

\section{Declarations}


Availability of data and materials

The datasets supporting the conclusions of this manuscript are included within the article and the supplementary information.

\section{Code Availability}

Not applicable.

\section{Authors' Contributions}

Joan Sanchez-Matos, Jose Adolfo de Almeida Neto and Ivon Pinheiro Lôbo contributed to the study conception and design. Material preparation, data collection and analysis were performed by Joan Sanchez-Matos, Lara Pinto de Araujo, Vinnícius Henrique Cerqueira da Silva and Raildo Mota de Jesus. All authors contributed equally to the interpretation of the results and the writing of the manuscript.

\section{Funding}

This research has been financed by Fundação de Amparo à Pesquisa do Estado da Bahia (project code: FAPESB No DTE 0023/2015 UESC.) and Coordenação de Aperfeiçoamento de Pessoal de Nível Superior.

\section{Declarations Ethics Approval}

Not applicable.

\section{Consent to Participate}

Not applicable.

\section{Consent for Publication (Include Appropriate Statements)}

Not applicable.

\section{Conflicts of Interest/Competing Interests}

The authors declare no conflict of interest.

\section{References}

1. Ben-Shahar Y (2018) The impact of environmental mn exposure on insect biology. Front Genet 9:17. https://doi.org/10.3389/fgene.2018.00070

2. Biancarosa I, Liland NS, Biemans D et al (2017) Uptake of heavy metals and arsenic in black soldier fly (Hermetia illucens) larvae grown on seaweed-enriched media. https://doi.org/10.1002/jsfa.8702 
3. Biasato I, Renna M, Gai F et al (2019) Partially defatted black soldier fly larva meal inclusion in piglet diets: effects on the growth performance, nutrient digestibility, blood profile, gut morphology and histological features. 1-11

4. Bosch G, Oonincx DGAB, Jordan HR et al (2019a) Standardisation of quantitative resource conversion studies with black soldier fly larvae Abstract. 1:1-15. https://doi.org/10.3920/JIFF2019.0004

5. Bosch G, Zanten HHE, Van, Zamprogna A et al (2019b) Conversion of organic resources by black soldier fl y larvae: Legislation, ef fi ciency and environmental impact. J Clean Prod 222:355-363. https://doi.org/10.1016/j.jclepro.2019.02.270

6. Braeckman B, Smagghe G, Brutsaert N et al (1999) Cadmium Uptake and Defense Mechanism in Insect Cells 1. 243:231-243

7. Buchwalter D, Luoma S (2005) Differences in Dissolved Cadmium and Zinc Uptake among Stream Insects: Mechanistic Explanations. Environ Sci Technol 39:498-504

8. Bulak P, Polakowski C, Nowak K et al (2018) Hermetia illucens as a new and promising species for use in entomoremediation. Sci Total Environ 633:912-919. https://doi.org/10.1016/j.scitotenv.2018.03.252

9. Cai M, Hu R, Zhang K et al (2018) Resistance of black soldier fly (Diptera: Stratiomyidae) larvae to combined heavy metals and potential application in municipal sewage sludge treatment. 15591567

10. Charlton AJ, Dickinson M, Wakefield ME et al (2015) Exploring the chemical safety of fly larvae as a source of protein for animal feed. 1:7-16. https://doi.org/10.3920/JIFF2014.0020

11. Chávez-Fuentes JJ, Capobianco A, Barbušová J, Hutňan M (2017) Manure from Our Agricultural Animals: A Quantitative and Qualitative Analysis Focused on Biogas Production. Waste Biomass Valoriz 8:1749-1757. https://doi.org/10.1007/s12649-017-9970-5

12. Chia SY, Tanga CM, Osuga IM et al (2019) Effect of dietary replacement of fishmeal by insect meal on growth performance, blood profiles and economics of growing pigs in Kenya. Animals 9:. https://doi.org/10.3390/ani9100705

13. Čičková H, Newton GL, Lacy RC, Kozánek M (2015) The use of fly larvae for organic waste treatment. Waste Manag 35:68-80. https://doi.org/10.1016/j.wasman.2014.09.026

14. Clark EW (1958) A review of literature on Calcium and Magnesium in insects. Ann Entomol Soc Am 51:142-154

15. Craig A, Hare L (1999) Experimental evidence for cadmium uptake via calcium channels in the aquatic insect Chironomus staegeri. 44:255-262

16. Dai SY, Jones B, Lee K et al (2016) Heavy Metal Contamination of Animal Feed in Texas. J Regul Sci $21-32$

17. Darlington MV, Meyer HJ, Graf G, Freeman TP (1983) The calcified puparium of the face fly, Musca autumnalis (Diptera: Muscidae). J Insect Physiol 29:. https://doi.org/10.1016/0022-1910(83)901397

Page $15 / 21$ 
18. Diener S, Zurbrügg C, Tockner K (2015a) Bioaccumulation of heavy metals in the black soldier fly, Hermetia illucens and effects on its life cycle. 1:261-270. https://doi.org/10.3920/JIFF2015.0030

19. Diener S, Zurbrügg C, Tockner K (2015b) Bioaccumulation of heavy metals in the black soldier fly, Hermetia illucens and effects on its life cycle. 1:261-270. https://doi.org/10.3920/JIFF2015.0030

20. Dierenfeld ES, King J (2008) Digestibility and Mineral Availability of Phoenix Worms, Hermetia illucens, Ingested by Mountain Chicken Frogs, Leptodactylus fallax. J Herpetol Med Surg 18:100105. https://doi.org/10.5818/1529-9651.18.3-4.100

21. Ding F, He Z, Liu S et al (2017) Heavy metals in composts of China: historical changes, regional variation, and potential impact on soil quality. Environ Sci Pollut Res 24:3194-3209. https://doi.org/10.1007/s11356-016-8057-3

22. Dube KA, McDonald DG, O'Donnell MJ (2000) Calcium homeostasis in larval and adult Drosophila melanogaster. Arch Insect Biochem Physiol 44(200005):27-39. https://doi.org/10.1002/(SICI)152063277 :AID-ARCH4>3.0.CO;2-I ) : 44:1<2

23. European Commission (2017) Commission Regulation (EU) 2017/893. Off J Eur Union 2017:1-643

24. European Commission (2021) Commission Regulation (EU) 2021/1372. Off J Eur Union 64:1-17

25. FAO FAOSTAT web site for statistics. In (2020) http://www.fao.org/faostat/en/\#data/QA. Accessed 5 Mar 2020

26. Fels-Klerx HJ, Van Der, Camenzuli L, Lee MK, Van Der, Oonincx DGAB (2016) Uptake of Cadmium, Lead and Arsenic by Tenebrio molitor and Hermetia illucens from Contaminated Substrates. https://doi.org/10.1371/journal.pone.0166186

27. Feng Z, Zhu H, Deng Q et al (2018) Environmental pollution induced by heavy metal(loid)s from pig farming. Environ Earth Sci 77:1-10. https://doi.org/10.1007/s12665-018-7300-2

28. Fengsong Z, Yanxia L, Ming Y et al (2011) Copper residue in animal manures and the potential pollution risk in Northeast China. J Resour Ecol 2:91-96. https://doi.org/10.3969/j.issn.1674764x.2011.01.013

29. Gao Q, Wang X, Wang W et al (2017) Influences of chromium and cadmium on the development of black soldier fly larvae. 8637-8644. https://doi.org/10.1007/s11356-017-8550-3

30. Gold M, Tomberlin JK, Diener S et al (2018) Decomposition of biowaste macronutrients, microbes, and chemicals in black soldier fly larval treatment : A review. Waste Manag 82:302-318. https://doi.org/10.1016/j.wasman.2018.10.022

31. Grodowitz MJ, Broce AB (1983) Calcium Storage in Face Fly (Diptera: Muscidae) Larvae for Puparium Formation1. Ann Entomol Soc Am 76:418-424. https://doi.org/10.1093/aesa/76.3.418

32. Guo T, Lou C, Zhai W et al (2018) Increased occurrence of heavy metals, antibiotics and resistance genes in surface soil after long-term application of manure. Sci Total Environ 635:995-1003. https://doi.org/10.1016/j.scitotenv.2018.04.194

33. Hejna M, Gottardo D, Baldi A et al (2018) Review: Nutritional ecology of heavy metals. Animal 12:2156-2170. https://doi.org/10.1017/S175173111700355X 
34. Hu Y, Cheng H, Tao S (2017) Environmental and human health challenges of industrial livestock and poultry farming in China and their mitigation. Environ Int 107:111-130.

https://doi.org/10.1016/j.envint.2017.07.003

35. Huang F, Wang L, Zhang C, Song xiao K (2017) Replacement of fishmeal with soybean meal and mineral supplements in diets of Litopenaeus vannamei reared in low-salinity water. Aquaculture 473:172-180. https://doi.org/10.1016/j.aquaculture.2017.02.011

36. Huis A Van (2019) Insects as food and feed, a new emerging agricultural sector: a review. 1:1-18. https://doi.org/10.3920/JIFF2019.0017

37. Hussein M, Pillai VV, Goddard JM et al (2017) Sustainable production of housefly (Musca domestica) larvae as a protein-rich feed ingredient by utilizing cattle manure. PLoS One 12:1-19. https://doi.org/10.1371/journal.pone.0171708

38. IPCC (2006) Guidelines for National Greenhouse Gas Inventories

39. Irungu FG, Mutungi CM, Faraj AK et al (2018) Minerals content of extruded fish feeds containing cricket (Acheta domesticus) and black soldier fly larvae (Hermetia illucens) fractions. Int Aquat Res 10:101-113. https://doi.org/10.1007/s40071-018-0191-8

40. Ji X, Shen Q, Liu F et al (2012) Antibiotic resistance gene abundances associated with antibiotics and heavy metals in animal manures and agricultural soils adjacent to feedlots in Shanghai; China. J Hazard Mater 235-236:178-185. https://doi.org/10.1016/j.jhazmat.2012.07.040

41. Lagos LV, Stein HH (2017) Chemical composition and amino acid digestibility of soybean meal produced in the United States, China, Argentina, Brazil, or India. J Anim Sci 95:1626-1636. https://doi.org/10.2527/jas2017.1440

42. Leclerc A, Laurent A (2017) Framework for estimating toxic releases from the application of manure on agricultural soil: National release inventories for heavy metals in 2000-2014. Sci Total Environ 590-591:452-460. https://doi.org/10.1016/j.scitotenv.2017.01.117

43. Li J, Xu Y, Wang L, Li F (2019) Heavy metal occurrence and risk assessment in dairy feeds and manures from the typical intensive dairy farms in China. Environ Sci Pollut Res 26:6348-6358. https://doi.org/10.1007/s11356-019-04125-1

44. Liu T, Kumar AM, Chen $\mathrm{H}$ et al (2019) Performance of black soldier fl y larvae (Diptera: Stratiomyidae) for manure composting and production of cleaner compost. 251:. https://doi.org/10.1016/j.jenvman.2019.109593

45. Liu X, Chen X, Wang H et al (2017) Dynamic changes of nutrient composition throughout the entire life cycle of black soldier fly. PLoS One 12:1-21. https://doi.org/10.1371/journal.pone.0182601

46. Matos JS, de Aráujo LP, Allaman IB et al (2021) Evaluation of the reduction of methane emission in swine and bovine manure treated with black soldier fly larvae (Hermetia illucens L.). Environ Monit Assess 193:. https://doi.org/10.1007/s10661-021-09252-2

47. Miranda CD, Crippen TL, Cammack JA, Tomberlin JK (2021) Black soldier fly, Hermetia illucens (L.) (Diptera: Stratiomyidae), and house fly, Musca domestica L. (Diptera: Muscidae), larvae reduce 
livestock manure and possibly associated nutrients: An assessment at two scales. Environ Pollut 282:116976. https://doi.org/10.1016/j.envpol.2021.116976

48. Negi S, Mandpe A, Hussain A, Kumar S (2020) Collegial effect of maggots larvae and garbage enzyme in rapid composting of food waste with wheat straw or biomass waste. J Clean Prod 258:120854. https://doi.org/10.1016/j.jclepro.2020.120854

49. Newton L, Craig S, Wes DW et al (2005) Using the black soldier fly, Hermetia illucens, as a valueadded tool for the management of swine manure. J Korean Entomol Appl Sci 36:17 pp

50. Nicholson FA, Chambers BJ, Williams JR, Unwin RJ (1999) Heavy metal contents of livestock feeds and animal manures in England and Wales. Bioresour Technol 70:23-31. https://doi.org/10.1016/S0960-8524(99)00017-6

51. Nordentoft S, Fischer C, Bjerrum L et al (2017) Reduction of Escherichia coli, Salmonella Enteritidis and Campylobacter jejuni in poultry manure by rearing of Musca domestica fly larvae Abstract. 3:145-153. https://doi.org/10.3920/JIFF2016.0058

52. Proc K, Bulak P, Wiącek D, Bieganowski A (2020a) Hermetia illucens exhibits bioaccumulative potential for 15 different elements - Implications for feed and food production. Sci Total Environ 723:138125. https://doi.org/10.1016/j.scitotenv.2020.138125

53. Proc K, Bulak P, Wiącek D, Bieganowski A (2020b) Hermetia illucens exhibits bioaccumulative potential for 15 different elements - Implications for feed and food production. Sci Total Environ 723:. https://doi.org/10.1016/j.scitotenv.2020.138125

54. Provolo G, Manuli G, Finzi A et al (2018) Effect of pig and cattle slurry application on heavy metal composition of maize grown on different soils. Sustain 10:. https://doi.org/10.3390/su10082684

55. Purschke B, Scheibelberger R, Axmann S et al (2017) Impact of substrate contamination with mycotoxins, heavy metals and pesticides on the growth performance and composition of black soldier fly larvae (Hermetia illucens) for use in the feed and food value chain fly. Food Addit Contam Part A 34:1410-1420. https://doi.org/10.1080/19440049.2017.1299946

56. Qian X, Wang Z, Shen G et al (2018) Heavy metals accumulation in soil after 4 years of continuous land application of swine manure: A field-scale monitoring and modeling estimation. Chemosphere 210:1029-1034. https://doi.org/10.1016/j.chemosphere.2018.07.107

57. Sahito OM, Kazi TG, Afridi HI et al (2016) Assessment of Toxic Metal Uptake by Different Vegetables Grown on Soils Amended with Poultry Waste: Risk Assessment. Water Air Soil Pollut 227:. https://doi.org/10.1007/s11270-016-3123-5

58. Schmitt E, Belghit I, Johansen J et al (2019) Growth and Safety Assessment of Feed Streams for Aquaculture Sludge. Animals 9:15

59. Setti L, Francia E, Pulvirenti A et al (2019) Use of black soldier fly (Hermetia illucens (L.), Diptera: Stratiomyidae) larvae processing residue in peat-based growing media. Waste Manag 95:278-288. https://doi.org/10.1016/j.wasman.2019.06.017

60. Shi T, Ma J, Wu F et al (2019) Mass balance-based inventory of heavy metals inputs to and outputs from agricultural soils in Zhejiang Province, China. Sci Total Environ 649:1269-1280. 
https://doi.org/10.1016/j.scitotenv.2018.08.414

61. Shi T, Ma J, Wu X et al (2018) Inventories of heavy metal inputs and outputs to and from agricultural soils: A review. Ecotoxicol Environ Saf 164:118-124. https://doi.org/10.1016/j.ecoenv.2018.08.016

62. Shumo M, Osuga IM, Khamis FM et al (2019) The nutritive value of black soldier fly larvae reared on common organic waste streams in Kenya. 1-13. https://doi.org/10.1038/s41598-019-46603-z

63. Spranghers T, Ottoboni M, Klootwijk C et al (2017) Nutritional composition of black soldier fly (Hermetia illucens) prepupae reared on different organic waste substrates. J Sci Food Agric 97:2594-2600. https://doi.org/10.1002/jsfa.8081

64. Stadtlander T, Stamer A, Buser A et al (2017) Hermetia illucens meal as fish meal replacement for rainbow trout on farm Abstract. 3:165-175. https://doi.org/10.3920/JIFF2016.0056

65. Sungur A, Soylak M, Yilmaz S, Ozcan H (2016) Heavy metal mobility and potential availability in animal manure: using a sequential extraction procedure. J Mater Cycles Waste Manag 18:563-572. https://doi.org/10.1007/s10163-015-0352-4

66. Tschirner M, Simon A (2015) Influence of different growing substrates and processing on the nutrient composition of black soldier fly larvae destined for animal feed. J Insects as Food Feed 1:249-259. https://doi.org/10.3920/JIFF2014.0008

67. Walker CH (1990) Kinetic Models to Predict Bioaccumulation of Pollutants. Funtional Ecol 4:295301

68. Wang H, Dong $Y$, Wang $H(2014)$ Hazardous metals in animal manure and their changes from 1990 to 2010 in China. Toxicol Environ Chem 96:1346-1355.

https://doi.org/10.1080/02772248.2015.1023305

69. Wang W, Zhang W, Wang X et al (2017) Tracing heavy metals in "swine manure - Maggot - chicken" production chain. Sci Rep 7:1-9. https://doi.org/10.1038/s41598-017-07317-2

70. Wang X, Wu N, Cai R-J, Geng, Wei-naXu X (2021) Changes in speciation, mobility and bioavailability of $\mathrm{Cd}, \mathrm{Cr}$ and As during the transformation process of pig manure by black soldier fly larvae (Hermetia illucens). J Integr Agric 20:1157-1166. https://doi.org/10.1016/S2095-3119(20)63333-0

71. Wu N, Wang X, Xu X et al (2020) Effects of heavy metals on the bioaccumulation, excretion and gut microbiome of black soldier fl y larvae (Hermetia illucens). Ecotoxicol Environ Saf 192:110323. https://doi.org/10.1016/j.ecoenv.2020.110323

72. Xiao X, Jin P, Zheng L et al (2018) Effects of black soldier fly (Hermetia illucens) larvae meal protein as a fishmeal replacement on the growth and immune index of yellow catfish (Pelteobagrus fulvidraco ). https://doi.org/10.1111/are.13611

73. Xu Y, Li J, Zhang X et al (2019) Data integration analysis: Heavy metal pollution in China's large-scale cattle rearing and reduction potential in manure utilization. J Clean Prod 232:308-317. https://doi.org/10.1016/j.jclepro.2019.05.337

74. Yu M, Li Z, Chen W, Rong T (2019) Use of Hermetia illucens larvae as a dietary protein source: Effects on growth performance, carcass traits, and meat quality in finishing pigs. Meat Sci 158:107837. https://doi.org/10.1016/j.meatsci.2019.05.008 
75. Zhao Y, Yan Z, Qin J, Xiao Z (2014) Effects of long-term cattle manure application on soil properties and soil heavy metals in corn seed production in Northwest China. Environ Sci Pollut Res 21:75867595. https://doi.org/10.1007/s11356-014-2671-8

76. Zhou F, Tomberlin JK, Zheng L, Yu Z (2013) Developmental and Waste Reduction Plasticity of Three Black Soldier Fly Strains (Diptera: Stratiomyidae) Raised on Different Livestock Manures Developmental and Waste Reduction Plasticity of Three Black Soldier Fly Strains ( Diptera : Stratiomyidae ) $\mathrm{R}$

77. Zhu FX, Yao YL, Wang SJ et al (2015) Housefly maggot-treated composting as sustainable option for pig manure management. Waste Manag 35:62-67. https://doi.org/10.1016/j.wasman.2014.10.005

78. Zubair M, Wang S, Zhang P et al (2020) Biological nutrient removal and recovery from solid and liquid livestock manure: Recent advance and perspective. Bioresour Technol 301:122823. https://doi.org/10.1016/j.biortech.2020.122823

\section{Figures}

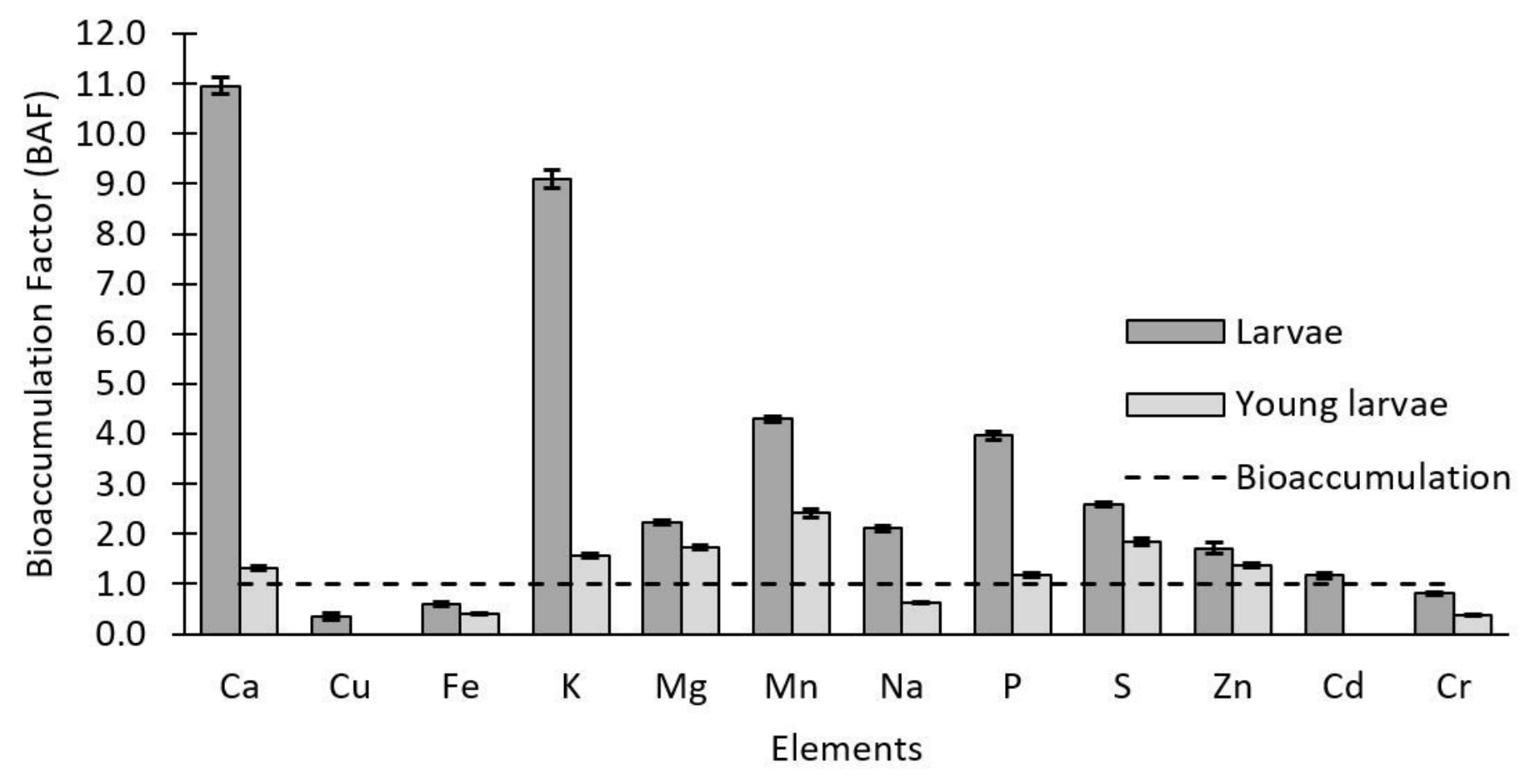

Figure 1

Bioaccumulation Factors (BAF) of different elements for Hermetia illucens larvae fed with cattle manure

\section{Supplementary Files}

This is a list of supplementary files associated with this preprint. Click to download. 
- S1SupplementaryMaterial.xlsx

Page 21/21 